\title{
Effects of Ketamine and Xylazine-Ketamine Combination in Clinical and Haemato-biochemical Parameters in Captive Rhesus Monkey (Macaca mulatta)
}

\author{
S. P. Kanu ${ }^{*}$, M. R. Alam², N. Hoda ${ }^{3}$ and K. P. Acharya ${ }^{4}$ \\ ${ }^{1}$ Bangladesh Agricultural University (BAU), Mymensingh \\ ${ }^{2}$ Department of surgery and Obstetrics, BAU, Mymensingh \\ ${ }^{3}$ Bangladesh National Zoo, Mirpur, Dhaka; \\ ${ }^{4 *}$ Regional veterinary lab, Pokhara, Kaski \\ *Corresponding author: drsurendra2065@gmail.com
}

\begin{abstract}
This study was carried to compare the effects of ketamine and xylazine-ketamine combination on clinical and haematobiochemical parameters in captive rhesus monkey. The animals were divided into two groups; one ketamine $(K)$ group and other xylazine-ketamine (XK) group. In ketamine group $(n=6)$ atropine sulphate and ketamine was used intramuscularly at the rate of $0.04 \mathrm{mg} / \mathrm{kg}$ body weight and $10 \mathrm{mg} /$ $\mathrm{kg}$ body weight respectively. In xylazine-ketamine group $(n=3)$ xylazine and ketamine was used intramuscularly at the rate of $1 \mathrm{mg} / \mathrm{kg}$ body weight and $5 \mathrm{mg} / \mathrm{kg}$ body weight respectively. Blood samples were collected immediately after induction and 30 min after induction in both groups. Effects of anaesthetics on haematological and biochemical parameters such as TEC, TLC, Hb, PCV, DLC, serum cholesterol, serum triglyceride, HDL and LDL and clinical parameters such as rectal temperature, heart rate, respiration rate, muscle relaxation, jaw tone, pedal reflex, palpebral reflex and position of eye ball were studied. Rectal temperature was significantly lower $(P<0.01)$ in group XK than in group $K$. Heart rate was significantly higher $(P<0.01)$ in group $K$ than in group XK. Respiratory rate was lower in group $K$ than in group XK but it was nonsignificant $(P>0.05)$. Hb and $P C V$ level was significantly lower $(P<0.05)$ in group $X K$ than group $K$. TEC and TLC was higher in group $K$ than in group XK but it was nonsignificant $(P>0.05)$. Neutrophil and Eosinophil was higher in group $X K$ than in group $K$ but it was nonsignificant $(P>0.05)$. Lymphocyte was lower in group $X K$ than in group $K$ but it was nonsignificant $(P>0.05)$. Monocyte was significantly lower $(P<0.05)$ in group $X K$ than in group $K$. Serum cholesterol was higher in group $X K$ than in group $K$ but it was nonsignificant $(P>0.05)$. Serum triglyceride and $L D L$ was significantly higher $(P<0.05)$ in group $X K$ than in group $K . H D L$ was lower in group $X K$ than in group $K$ but it was nonsignificant $(P>0.05)$. Smooth induction was
\end{abstract}


found in group XK and duration of anaesthesia was longer in group XK whereas smooth recovery was found in group $K$ but duration of anaesthesia was shorter. Muscle relaxation was excellent in group $X K$ in comparison to group $K$. It can be suggested from the results of this study that for shorter duration of anaesthesia only ketamine can be used but for longer duration, xylazine-ketamine combination will be appropriate.

Keywords: Anesthesia; Monkey; Surgery; Wildlife

\section{INTRODUCTION}

Monkeys are wild animals that belong to order primates. They are abundantly found in forests all over the world. Besides forest, they are also found in temple areas and human residents where plenty of trees are present. They are also kept captive in zoo as an important zoo animal. They are said to be ancestor of human beings. Their genetic property is very close to human beings, chimpanzee and gorilla (Patterson et al., 2006). In Hindu religion monkey is regarded as symbol of god Hanuman (Jones and Ryan, 2006).

Ketamine hydrochloride is widely used anaesthetic in wild animals. It is used alone or in combination with various sedatives and tranquilizers such as xylazine hydrochloride, diazepam, medetomidine (Naccarato and Hunter, 1979). The addition of xylazine increases the duration of anaesthesia. Ketamine is the drug of choice when animal has to be sedated prior to fasting in emergency cases such as accidents and animal bites. Other anaesthetics such as thiopentone and propofol are used intravenously once the animal becomes calm/ sedated. Once the animal is sedated, inhalant anaesthetics such as methoxyflurane, halothane, isoflurane and sevoflurane are used for maintenance. Xylazine is used as a sole agent for minor diagnostic procedures or manipulative procedures. Xylazine is used for short procedures to make the animal calm and safe. It is used as preanaesthetic sedative prior to local, regional or epidural anaesthesia. It is combined with opoids to produce profound sedation and analgesia (Paddleford, 1999).

Common surgical affections found in monkeys are wounds (incised wounds, biting wounds, lacerated wounds, and traumatic wounds), fracture (closed or open), lameness due to several causes. Sedation are used for various purposes like; to stitch or dress the wound, to correct fracture, lameness or for other procedures such as physical examination, blood collection, transportation from one place to another. For safety of handlers also, anaesthesia is required. Monkey is difficult to handle and may cause severe injury to the handler and other persons around. When used under laboratory conditions, these animals produce unique hazards to handlers, particularly zoonotic infection (Young et al., 1999). Proper anaesthesia reduces the physiological stress of 
the animals also. Keeping all these things in mind, this study was undertaken to find out a good anaesthetic or anaesthetic combinations and their effects on monkey to carry out minor or major surgical/ clinical procedures safely. The objectives of this study include to compare the effects of ketamine and xylazine-ketamine combination for anaesthesia in monkeys and to know the effects of these anesthetics on haematobiochemical parameters such as complete blood cell count (CBC), serum cholesterol, triglycerides, high density lipoprotein (HDL) and low density lipoprotein (LDL) and clinical parameters such as rectal temperature, heart rate, respiration, pedal reflex, palpebral reflex, jaw tone and muscle relaxation.

\section{MATERIALS AND METHODS}

The experiment was done in Bangladesh National Zoo, Mirpur-1, Dhaka during the period of January to May 2017. Nine apparently healthy monkeys were chosen for experiment. In one group there were six monkeys and in other group there were 3 monkeys. Their age ranged from 2-8 years and weight ranged from 4-12 kg. Monkeys of either sex (male or female) were used. They were housed in well ventilated tin shed having concrete floor. They had ad libitum access to food and water. In zoo, they were given bread, fruits, eggs, vegetables, ground nuts and grams about $1.5 \mathrm{~kg}$ food/ animal/ day. The experimental animals were divided into 2 groups.

\section{a) Ketamine (K) Group}

In this group there were 6 animals. Atropine sulphate was used as preanaesthetic at the rate of $0.04 \mathrm{mg} / \mathrm{kg}$ body weight and ketamine was used as anaesthetic agent at the rate of $10 \mathrm{mg} / \mathrm{kg}$ body weight intramuscularly (IM).

\section{b) Xylazine-Ketamine (XK) Group}

In this group there were 3 animals. Xylazine was used as sedative at the rate of $1 \mathrm{mg} /$ $\mathrm{kg}$ body weight and ketamine was used as anaesthetic at the rate of $5 \mathrm{mg} / \mathrm{kg}$ body weight intramuscularly (IM).

\section{Experimental procedure}

The monkeys in squeeze cage were used in ketamine group $(\mathrm{K})$ and the monkeys in shed were used for xylazine-ketamine group (XK). In ketamine $(\mathrm{K})$ group, ketamine $\mathrm{HCl}$ (G-Ketamine ${ }^{\circledR}, 50 \mathrm{mg} / \mathrm{ml}$, Gonoshasthaya Pharmaceuticals Ltd, Bangladesh) and atropine sulphate (Atrovet, $1 \mathrm{mg} / \mathrm{ml}$, Techno Drugs Ltd., Bangladesh) was given intramuscularly by squeezing the animal in squeeze cage. Animal was taken out from the cage when they were recumbent on floor. In xylazine-ketamine (XK) group xylazine and ketamine was drawn in a single syringe and monkeys were darted in their shed by using blow pipe. The animals were taken out of the shed when they 
were recumbent on the floor.

In both the groups after the animals were anaesthetized and safe to handle, clinical parameters were taken. Rectal temperature was taken with mercury thermometer; heart rate was taken by auscultating with stethoscope and respiration rate was taken by observing chest rise and fall. Pedal reflex was noted by pinching the digits, palpebral reflex was noted by touching the eyelid with finger, jaw tone was felt by opening the mouth with finger, muscle relaxation was felt by extending and flexing the hand of animal and position of eye ball was noted by observing eye. These parameters were noted immediately after induction when the animal was brought out of cage/ shed and then $30 \mathrm{~min}$ after induction.

In both groups, blood was collected from either radial or saphanous vein immediately after induction and then 30 min after induction. Collected blood was kept in $\mathrm{K}_{2}$ EDTA $3 \mathrm{ml}$ tube (Cure Medical Tech Co., Ltd., USA) for complete blood cell count (CBC) and serum clot activator $4 \mathrm{ml}$ tube (Cure Medical Tech Co., Ltd., USA) for serum collection. Collected blood was brought in cool box to Bangladesh Agriculture University (BAU) and was manually examined in Physiology Laboratory, Department of Physiology, BAU for total erythrocyte count (TEC), total leucocyte count (TLC), haemoglobin $(\mathrm{Hb})$, packed cell volume (PCV) and differential leucocyte count (DLC) by the method described by Shastry (Sastry,1989). In lipid profile, parameters such as cholesterol, triglyceride, high density lipopropein (HDL) and low-density lipoprotein (LDL) were determined by using 3000 evolution semiautomatic biochemistry analyser. Detailed procedure is illustrated in the diagram (Fig 1). The data obtained in the present investigation were analysed by repeated measures analysis of variance and students" "t" test.

\section{RESULTS}

\section{Effects of anaesthetics on clinical parameters in monkey}

\section{Rectal temperature}

The normal temperature in rhesus monkey is $98.06-102.02{ }^{\circ} \mathrm{F}$ (Bourne 1975; Bush et al., 1977; Liu and Delauter, 1977). Rectal temperature was within normal range in both groups $\mathrm{K}$ and $\mathrm{XK}$ immediately after induction and 30 min after induction. Rectal temperature in group XK was significantly lower $(P<0.01) 30 \mathrm{~min}$ after induction in comparison to that of group $\mathrm{K}$. In macaques, a similar decrease in body temperature was observed during anesthesia with ketamine, but this was followed by post-anesthetic hyperthermia (Lopez et al., 2002). These findings are in agreement with the present study where temperature slightly increased with ketamine but decreased by approximately $1^{\circ} \mathrm{F}$ with xylazine-ketamine anaesthesia. The effects of 
anaesthetics on rectal temperature is given in Table 1.

\section{Heart rate}

The normal value of heart rate in rhesus monkey is 100-120/ min (Bourne, 1975; Johnson-Delaney, 1994; Haruo, 1995). The heart rate in group K was significantly higher $(P<0.05)$ immediately after induction and 30 minutes after induction in comparison to that of group XK. Xylazine has cardiodepressant action on heart rate (Grub et al., 2008).

Thurmon (1996) reported that ketamine had cardiovascular depression in rhesus monkey up to $30 \mathrm{~min}$. This is in agreement with the findings of the present study where heart rate decreased after 30 min while using ketamine only and increased after 30 min while using xylazine-ketamine combination. The effects of anaesthetics on heart rate is given in Table 1 .
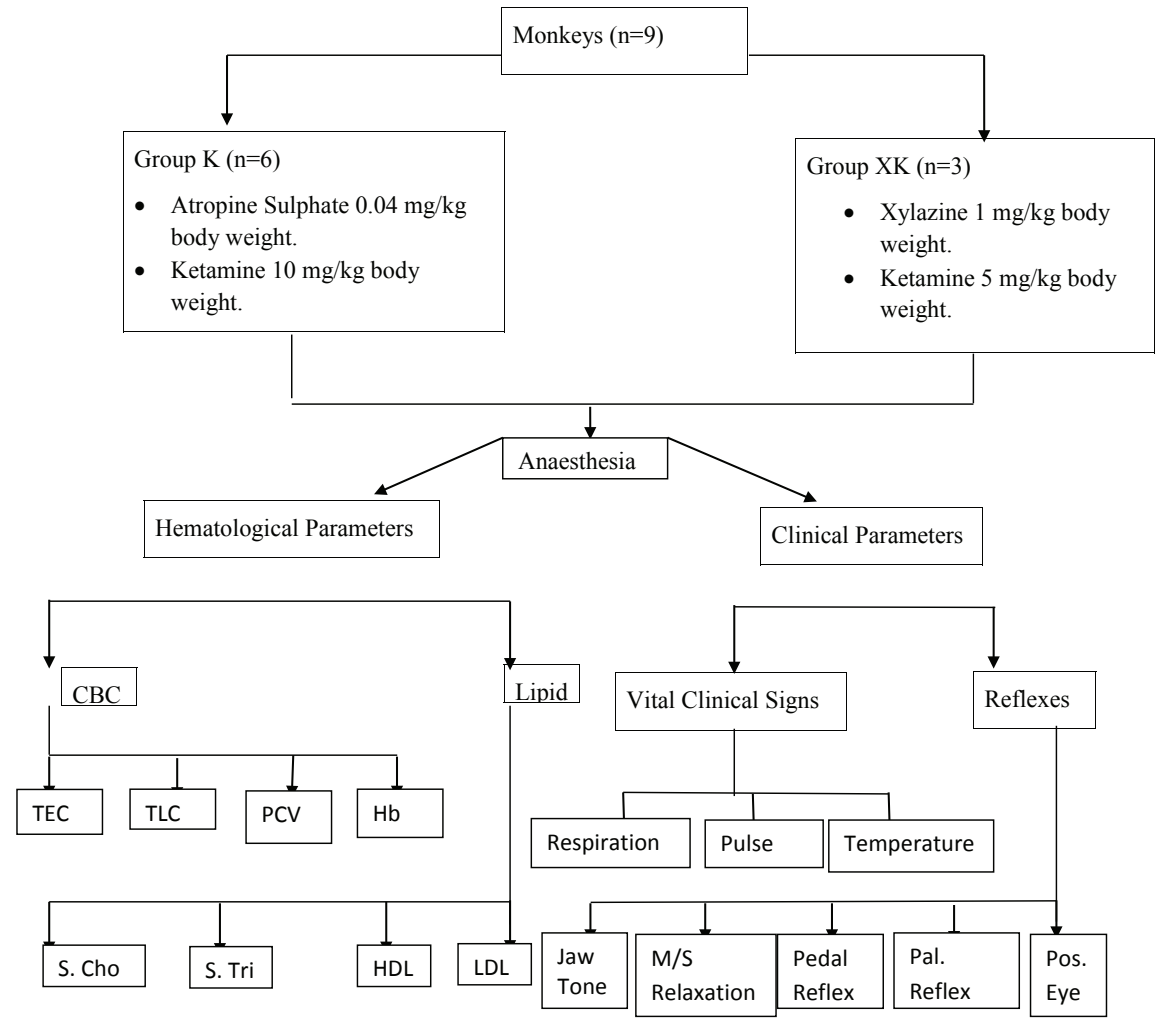

Figure 1. Layout of the experiment.

Table 1: Effects of anaesthetics on clinical parameters in monkey 


\begin{tabular}{|l|l|l|l|}
\hline \multicolumn{1}{|c|}{ Parameters } & Anaesthetic agents & $\begin{array}{c}\text { Immediately after } \\
\text { induction }\end{array}$ & \multicolumn{1}{c|}{$\begin{array}{c}\text { 30 min after } \\
\text { induction }\end{array}$} \\
\hline Rectal temperature & $\mathrm{K}(\mathrm{n}=6)$ & $101 \pm 0.6$ & $101.45 \pm 1.05$ \\
\cline { 2 - 4 } & $\mathrm{XK}(\mathrm{n}=3)$ & $100.86 \pm 0.61$ & $98.93 \pm 0.31 * *$ \\
\hline \multirow{2}{*}{ Heart rate } & $\mathrm{K}(\mathrm{n}=6)$ & $182.66 \pm 25.88$ & $170.66 \pm 23.14$ \\
\cline { 2 - 4 } & $\mathrm{XK}(\mathrm{n}=3)$ & $90.66 \pm 10.06^{* *}$ & $97.33 \pm 6.11^{* *}$ \\
\hline \multirow{2}{*}{ Respiration rate } & $\mathrm{K}(\mathrm{n}=6)$ & $42.33 \pm 9.99$ & $46.66 \pm 21.86$ \\
\cline { 2 - 5 } & $\mathrm{XK}(\mathrm{n}=3)$ & $45.33 \pm 6.11$ & 32 \\
\hline
\end{tabular}

$\pm=$ Standard deviation $\quad * *=$ Significant at $1 \%$ level of probability between the group

$\mathrm{K}=$ Ketamine $\mathrm{XK}=$ Xylazine-ketamine

\section{Respiration rate}

The normal respiration rate in rhesus monkey is 20-50/ min (Bush et al., 1977; Liu and DeLauter, 1977). Respiration rate increased in group $\mathrm{K}$ and decrease in group $\mathrm{XK}$ after $30 \mathrm{~min}$ of induction which was nonsignificant $(P>0.05)$. Xylazine may cause respiratory depression (Paddleford, 1999). Ketamine, in contrast to most of the anesthetic drugs, has shown to possess incremental effects on the heart rate, blood pressure and respiratory rate due to increase in sympathetic activation (Von UngernSternberg et al., 2007). The effects of anaesthetics on respiration rate is given in Table 1.

\section{Effects of anaesthetics on haematological parameters in monkey}

\section{Haemoglobin}

The normal value of haemoglobin in rhesus monkey is $12.5 \pm 1.5 \mathrm{gm} / \mathrm{dl}$ (Fowler, 1986). In group XK, mean value of haemoglobin was recorded as $8.13 \pm 0.83$ which decreased to $7.8 \pm 0.72$ after 30 min of induction and was significant $(P<0.05)$ within the group. Mean value of haemoglobin was significantly higher $(P<0.05)$ in group $\mathrm{K}$ after $30 \mathrm{~min}$ of induction in comparison to that of group XK. The effects of anaesthetics on haemoglobin is given in Table 2.

\section{Packed cell volume (PCV)}

The normal packed cell volume in rhesus monkey is $40.3 \pm 3.5 \%$ (Fowler, 1986). The mean value of packed cell volume immediately after induction was significantly higher $(P<0.05)$ in group $\mathrm{K}$ in comparison to that of group XK. The mean value of 
packed cell volume was significantly higher $(P<0.01)$ after 30 min of induction in group $\mathrm{K}$ in comparison to that of group XK. The effects of anaesthetics on packed cell volume is given in Table 2 .

\section{Total erythrocyte count (TEC)}

The normal value of total erythrocyte count in rhesus monkey is $4.48 \pm 0.63 \mathrm{~mm} /$ $\mathrm{cm}^{3}$ (Fowler, 1986). The mean values of total erythrocyte count were nonsignificant $(P>0.05)$ both within and between groups $\mathrm{K}$ and XK immediately after induction and 30 min after induction. The effects of anaesthetics on total erythrocyte count is given in Table 2.

Table 2: Effects of anaesthetics on haematological parameters in monkey

\begin{tabular}{|c|c|c|c|c|}
\hline \multicolumn{2}{|l|}{ Parameters } & $\begin{array}{l}\text { Anaesthetic } \\
\text { agents }\end{array}$ & $\begin{array}{l}\text { Immediately } \\
\text { after induction }\end{array}$ & $\begin{array}{l}30 \text { min after } \\
\text { induction }\end{array}$ \\
\hline \multirow{2}{*}{\multicolumn{2}{|c|}{$\begin{array}{l}\text { Haemoglobin }(\mathrm{gm} / \mathrm{dl}) \\
\mathrm{XK}(\mathrm{n}=3)\end{array}$}} & $\mathrm{K}(\mathrm{n}=6)$ & $9.18 \pm 1.31$ & $9.4 \pm 1.14$ \\
\hline & & $8.13 \pm 0.83^{\mathrm{a}}$ & $7.8 \pm 0.72 *$ & \\
\hline \multirow{2}{*}{\multicolumn{2}{|c|}{$\begin{array}{l}\text { Packed cell volume }(\%) \\
\mathrm{XK}(\mathrm{n}=3)\end{array}$}} & $\mathrm{K}(\mathrm{n}=6)$ & $38.08 \pm 3.54$ & $39.58 \pm 5.01$ \\
\hline & & $32.33 \pm 3.05^{*}$ & $31.33 \pm 0.57 * *$ & \\
\hline \multirow{2}{*}{\multicolumn{2}{|c|}{$\begin{array}{l}\text { Total erythrocyte count }(\mathrm{mm} / \mathrm{cm} 3) \\
\mathrm{XK}(\mathrm{n}=3)\end{array}$}} & $\mathrm{K}(\mathrm{n}=6)$ & $5.45 \pm 0.74$ & $5.65 \pm 0.88$ \\
\hline & & $5.49 \pm 0.89$ & $5.15 \pm 0.89$ & \\
\hline \multirow{2}{*}{\multicolumn{2}{|c|}{$\begin{array}{l}\text { Total leucocyte count (thou/cm } 3 \text { ) } \\
\text { XK(n=3) }\end{array}$}} & $\mathrm{K}(\mathrm{n}=6)$ & $15.86 \pm 13.70$ & $8.97 \pm 2.96$ \\
\hline & & $8.63 \pm 0.42$ & $8.26 \pm 0.33$ & \\
\hline \multirow{10}{*}{$\begin{array}{l}\text { Differential } \\
\text { le ucocyte } \\
\text { count }(\%)\end{array}$} & \multirow[t]{2}{*}{ Neutrophil } & $\mathrm{K}(\mathrm{n}=6)$ & $59.5 \pm 8.47$ & $60.16 \pm 12.71$ \\
\hline & & $\mathrm{XK}(\mathrm{n}=3)$ & $57.67 \pm 20.50$ & $72.66 \pm 1.15$ \\
\hline & \multirow[t]{2}{*}{ Lymhocyte } & $\mathrm{K}(\mathrm{n}=6)$ & $35.33 \pm 8.61$ & $35 \pm 13.78$ \\
\hline & & $\mathrm{XK}(\mathrm{n}=3)$ & $37.33 \pm 17.90$ & $22.66 \pm 1.15$ \\
\hline & \multirow[t]{2}{*}{ Monocyte } & $\mathrm{K}(\mathrm{n}=6)$ & $2.66 \pm 1.3$ & $2.66 \pm 1.2$ \\
\hline & & $\mathrm{XK}(\mathrm{n}=3)$ & $1 \pm 0$ & $1.66 \pm 0.57$ \\
\hline & \multirow[t]{2}{*}{ Eosinophil } & $\mathrm{K}(\mathrm{n}=6)$ & $2.5 \pm 1.97$ & $2.16 \pm 2.13$ \\
\hline & & $\mathrm{XK}(\mathrm{n}=3)$ & $2.64 \pm 0.47$ & $3 \pm 1$ \\
\hline & \multirow[t]{2}{*}{ Basophil } & $\mathrm{K}(\mathrm{n}=6)$ & 0 & 0 \\
\hline & & $\mathrm{XK}(\mathrm{n}=3)$ & 0 & 0 \\
\hline
\end{tabular}

* = Significant at $5 \%$ level of probability between the group 
$\underline{a}=$ significant at $5 \%$ level of probability within the group

$* *=$ Significant at $1 \%$ level of probability between the groups

\section{Total leucocyte count (TLC)}

The normal value of total leucocyte count in rhesus monkey is $11.5 \pm 4.3$ thou/ $\mathrm{cm}^{3}$ (Fowler, 1986). The mean values of total leucocyte count were nonsignificant $(P>0.05)$ both within and between groups $\mathrm{K}$ and XK immediately after induction and $30 \mathrm{~min}$ after induction. The effects of anaesthetics on total leucocyte count is given in the Table 2.

\section{Effects of anaesthetics on differential leucocyte count (DLC)}

The normal value of neutrophil, lymphocyte, monocyte, eosinophil and basophil count in rhesus monkey are 39.09 $\pm 11.97 \%, 57.40 \pm 12.61 \%, 2.29 \pm 1.23 \%$, $0.43 \pm 0.61 \%$, and $0.06 \pm 0.24 \%$ respectively (Chen et al., 2009). The mean value of monocyte immediately after induction was significantly higher $(P<0.05)$ in group $\mathrm{K}$ in comparison to that of group XK. The mean value of neutrophil, lymphocyte, eosinophil and basophil was nonsignificant $(P>0.05)$ both within and between the groups $\mathrm{K}$ and $\mathrm{XK}$ immediately after induction and $30 \mathrm{~min}$ after induction. The effects of anaesthetics on differential leucocyte count is given in the Table 2.

In a study on the haematology of vervet monkeys, Wall et al., (1985) found that PCV decreased in ketamine anaesthetized groups which may be due to sequestration of erythrocytes in the capillary beds. A similar decrease in PCV has been noted in ketamine anaesthesia in rhesus monkeys (Loomis et al., 1980) as well as in other species with other anaesthesia (Kocan et al., 1981) which is dissimilar to the results obtained in this study.

According to Bennet et al., (1992) decrease in total erythrocyte count (TEC), hemoglobin $(\mathrm{Hb})$ concentration, total leucocyte count (TLC) and lymphocyte count, following ketamine injection in rhesus monkeys (Macaca mulatta), can be attributed to a reversal of stress or "alarm reaction". Loomis et al., (1980) and Wall et al., (1985) working with rhesus and vervet monkeys, also observed a decrease in peripheral erythrocytes and lymphocytes.

This observation is similar to results of the present study where TLC has decreased whereas TEC and $\mathrm{Hb}$ concentration has increased with ketamine anaesthesia. In case of XK combination TEC, TLC, Hb concentration and lymphocyte count has decreased which is similar to the results obtained by Loomis et al., (1980), Wall et al., (1985) and Bennet et al., (1992). The decrease in blood cellular elements may 
be due to haemodilution by infiltration of intestinal fluids during immobilization (Drevemo and Karstad, 1974). The fall in PCV and TEC may be due to lytic effects of xylazine (Moor and Desmet, 1971).

\section{Effects of anaesthetics on lipid parameters in monkey}

\section{Serum cholesterol}

The normal value of serum cholesterol in rhesus monkey is $32.48 \pm 8.51 \mathrm{mg} / \mathrm{dl}$ (Chen et al., 2009). The mean value of serum cholesterol was much higher than normal in both groups $\mathrm{K}$ and $\mathrm{XK}$ immediately after induction and $30 \mathrm{~min}$ after induction but nonsignificant $(P>0.05)$. The effects of anaesthetics on serum cholesterol is given in Table 3.

\section{Serum triglyceride}

The normal value of serum triglyceride in rhesus monkey is $261.29 \pm 46.05 \mathrm{mg} / \mathrm{dl}$ (Chen et al., 2009). The level of serum triglyceride was significantly higher $(P<0.05)$ 30 min after induction in group XK in comparison to that of group K. The effects of anaesthetics on serum triglyceride is given in Table 3.

Table 3: Effects of anaesthetics on lipid parameters in monkey

\begin{tabular}{|l|l|l|l|}
\hline Parameters & $\begin{array}{l}\text { Anaesthetic } \\
\text { agents }\end{array}$ & $\begin{array}{l}\mathbf{I} \text { m m e d i a t e ly } \\
\text { after induction }\end{array}$ & $\begin{array}{l}\text { 30 min after } \\
\text { induction }\end{array}$ \\
\hline \multirow{2}{*}{ Serum cholesterol $(\mathrm{mg} / \mathrm{dl})$} & $\mathrm{K}(\mathrm{n}=6)$ & $125.33 \pm 47.70$ & $123.66 \pm 43.84$ \\
\cline { 2 - 4 } & $\mathrm{XK}(\mathrm{n}=3)$ & $137.66 \pm 30.98$ & $136.33 \pm 26.10$ \\
\hline \multirow{2}{*}{ Serum Triglyceride $(\mathrm{mg} / \mathrm{dl})$} & $\mathrm{K}(\mathrm{n}=6)$ & $107.66 \pm 72.84$ & $97.83 \pm 63.41$ \\
\cline { 2 - 4 } & $\mathrm{XK}(\mathrm{n}=3)$ & $136.66 \pm 77.41$ & $130.66 \pm 74.01^{\mathrm{a}}$ \\
\hline \multirow{2}{*}{ High Density lipoprotein $(\mathrm{mg} / \mathrm{dl})$} & $\mathrm{K}(\mathrm{n}=6)$ & $60.20 \pm 20.33$ & $56.5 \pm 11.22$ \\
\cline { 2 - 4 } & $\mathrm{XK}(\mathrm{n}=3)$ & $54.66 \pm 12.42$ & $54.33 \pm 16.44$ \\
\hline Low density lipoprotein $(\mathrm{mg} / \mathrm{dl})$ & $\mathrm{K}(\mathrm{n}=6)$ & $45.56 \pm 31.54$ & $47.43 \pm 32.13$ \\
\hline & $\mathrm{XK}(\mathrm{n}=3)$ & $60.20 \pm 20.33$ & $64.53 \pm 18.72^{*}$ \\
\hline
\end{tabular}

$\mathrm{a}=$ Significant at $5 \%$ level of probability within the group

$*=$ Significant at $5 \%$ level of probability between the group

\section{High density lipoprotein (HDL)}


The normal value of high-density lipoprotein is $49.49 \pm 11.60 \mathrm{mg} / \mathrm{dl}$ (Chen et al., 2009). The mean values of high-density lipoprotein immediately after induction and 30 min after induction was nonsignificant $(P>0.05)$ within and between the groups $\mathrm{K}$ and XK. The effects of anaesthetics on high density lipoprotein is given in Table 3.

\section{Low density lipoprotein (LDL)}

The normal value of LDL in rhesus monkey is $78.86 \pm 15.08 \mathrm{mg} / \mathrm{dl}$ (Chen et al., 2009). The mean value of low-density lipoprotein was significantly higher $(P<0.05)$ after 30 min of induction in group XK in comparison to that of group $\mathrm{K}$. The effects of anaesthetics on low density lipoprotein is given in Table 3.

\section{DISCUSSION}

A study on serum lipid parameters in adult bonnet monkeys (Macaca radiate) by Perumal et al., (2007) showed that ketamine anesthesia caused significant decreases in serum cholesterol and HDL which is dissimilar to the results obtained in my study. Studies on ketamine anesthesia in aged bonnet monkeys caused no significant alteration in serum cholesterol level; this apparently contradictory result might reflect the age of the animals (Venkatesan et al., 2006). Plasma cholesterol level is under the direct influence of the liver and the stress response (Gelhot et al., 1997). Lipolysis increases under the influence of catecholamines and corticosteroids and contributes to fat metabolism.

Many studies reported age-related changes in lipid concentrations in nonhuman primates. HDL tended to decline with the progression of age in normal rhesus monkeys, whereas serum triglycerides, cholesterol, and LDL remained unchanged (Tigno et al., 2004). In another study of rhesus monkeys, only triglyceride level is found to increase with the advancement of age (Smucny et al., 2001). In Tibetan macaques, it is found that cholesterol, HDL, and apolipoprotein $\mathrm{A}_{1}$ decreased with age, but triglyceride and LDL levels remained the same (Wu et al., 2014).

\section{CONCLUSION}

The following conclusions can be made from the findings of the present study. Rectal temperature and respiration rate decreased in both groups ketamine and xylazineketamine combination. Heart rate remained much above normal when only ketamine was used but remained almost stable when used in combination with xylazine. TEC, $\mathrm{Hb}$ and PCV increased and TLC decreased in ketamine group and TEC, TLC, Hb and PCV decreased in xylazine-ketamine combination group. In DLC only neutrophil increased in ketamine group and only lymphocyte decreased in xylazine-ketamine combination group. In lipid profile serum cholesterol, serum triglyceride and HDL decreased in both ketamine group and xylazine-ketamine combination group, whereas 
LDL increased in both groups, ketamine and xylazine-ketamine combination.

\section{REFERENCES}

Bennet JS, Gosset KA, McCartht MP and Simpson ED. 1992. Effects of ketamine hydrochloride on serum biochemical and hematologic variables in rhesus monkeys (Macaca mulatta). Veterinary Clinical Pathology. 21(1): 15-18.

Bourne GH. 1975. The Rhesus Monkey. London: Academic Press.

Bush M, Custer R, Smeller J. and Bush LM. 1977. Physiologic measures of nonhuman primates during physical and chemical immobilization. Journal of the American Veterinary Medical Association. 171(9): 866-869.

Chen Y, Qin S, Ding Y, Wei L, Zhang J, Li H, Bu H, Lu Y and Cheng J. 2009. Reference values of clinical chemistry and hematology parameters in rhesus monkeys (Macaca mulatta). Xenotransplantation. 16(6): 496-501.

DeMoor A. 1971. Effect of rompun on acid-base-equilibrium and arterial $\mathrm{O}_{2}$ pressure in cattle. Veterinary Medical Review. 213: 163-169.

Drevemo S and Karstad L. 1974. The effect of xylazine and xylazine-etorphineacepromazine combinations on some clinical and hematological parameters in impala and eland. Journal of Wildlife Diseases. 10(4): 377-383.

Fowler ME. 1986. Zoo and wild animal medicine. 2nd edn. W.B. Saunders Company. pp. 706-707.

Gehlot A, Godhwani JL, Godhwani S, Aseri ML, Jain P and Vyas MCR. 1997. Sound stress-induced changes and their modification by drugs in albino rats: an experimental study. Indian Journal of Pharmacology. 29(3): 187-189.

Grubb TL, Benson GJ, Thurmon JC, Olson WO, Tranquilli WJ, Foreman JH, Constable PD and Davis LE. 2008. Effects of xylazine/ketamine on cardiac function and serum ionised calcium in horses. Veterinary Anaesthesia and Analgesia. 24(2): 6-11.

Haruo M.1995. Ventricular wall thickness and blood pressure values in normal cynomolgus monkeys. Journal of Veterinary Medical Science, 57(6):10451048 .

Johnson-Delaney C. 1994. Primates. The Veterinary Clinics of North America. Small Animal Practice. 24(1): 121-156.

Jones AC and Ryan JD. 2006. Encyclopaedia of hinduism. Infobase publishing. pp. 
177-178.

Kocan A, Glenn B, Thedford T, Doyle R, Waldrup K, Kubar G and Shaw MO. 1981. Effects of chemical immobilization on haematologic and serum chemical values in captive white-tailed deer. Journal of the American veterinary Medical Association. 179(11): 1153-1156.

Liu C and DeLauter R. 1977. Pulmonary functions in concious and anesthetized rhesus macaques. American Journal of Veterinary Research 38(11): 18431848.

Loomis MR, Henrickson RV and Anderson JH. 1980. Effects of ketamine hydrochloride on the haemogram of rhesus monkey (Macaca mulatta). Laboratory animal science. 30(5): 851-853.

Lopez KR, Gibbs PH and Reed DS. 2002. A comparison of body temperature changes due to the administration of ketamine-acepromazine and tiletaminezolazepam anesthetic in cynomolgus macaques. Journal of the American Association for Laboratory Animal Science. 41(2): 47-50.

Naccarato EF and Hunter WS. 1979. Anaesthetic effects of various ratios of ketamine and xylazine in rhesus monkeys (Macaca mulatta). Laboratory Animals. 13(4): 317-319.

Paddleford RR. 1999. Anaesthetic agents. In: Manual of Small Animal Anaesthesia. 2nd edn. W. B. Saunders Company. pp. 22-47.

Paddleford RR. 1999. Preanaesthetic agents. In: Manual of Small Animal Anaesthesia. 2nd edn. W. B. Saunders Company. pp. 12-24.

Patterson N, Ritcher DJ, Gnerre S, Landr ES and Reich D. 2006. Genetic evidence for complex speciation of humans and chimpanzees. Nature. 441(7097): 1103-1108.

Perumal N, Ramasamy V, Kumar MM and Majumdar SS. 2007. Effects of ketamine and thiopentone anesthesia on serum lipid parameters in adult bonnet monkeys (Macaca radiata). Journal of the American Association for Laboratory Animal Science. 46(3): 21-3.

Sastry GA. 1989. Veterinary clinical Pathology. 3rd edn. CBS Publishers and Distributors P Ltd, New Delhi. pp. 1-25.

Smucny DA, Allison DB, Ingram DK, Roth GS, Kemnitz JW, Kohama SG and Lane MA. 2001. Changes in blood chemistry and hematology variables during 
aging in captive rhesus macaques (Macaca mulatta). Journal of Medical Primatology. 30: 161-173.

Thurman JC, Tranquilli WJ and Benson GJ. 1996. Anesthesia of wild, exotic and laboratory animals. Lumb \& Jones' veterinary anesthesia. pp. 686-735.

Tigno XT, Gerzanich G and Hansen BC. 2004. Age-related changes in metabolic parameters of nonhuman primates. The journals of gerontology series a: biological sciences and medical sciences. 59 (11): 1081-1088.

Venkatesan R, Nagarajan P, Ravishankar R and Majundar SS. 2006. Hematologic and serum biochemical values in aged bonnet macaques anesthetized with ketamine hydrochloride. Journal of American Association of Laboratory Animal Science. 45: 45-48.

Von Ungern Sternberg BS, Regli A, Frei FJ, Ritz E, Jordi M, Hammer J, Schibler A and Erb TO. 2007. A deeper level of ketamine anesthesia does not affect functional residual capacity and ventilation distribution in healthy preschool children. Pediatric Anesthesia. 17(12): 1150-1155.

Wall HS, Worthman C and Else JG. 1985. Effects of ketamine aanesthesia, stress and repeated bleeding on the haematology of vervet monkeys. Laboratory animals. 19(2): 138-144.

Wu D, Yi Y, Sun F, Zhou L, Yang F, Wang H, Zhang G, Zhang YA and Yue F. 2014. Effects of age and sex on the haematology and blood chemistry of tibetan macaques (Macaca thibetana). Journal of the American Association Laboratory Animal Science. 53(1): 12-17.

Young SS, Schilling AM, Skens S and Ritacco G. 1999. Short duration anaesthetic with medetomidine and ketamine in cynomolgus monkeys. Laboratory Animals. 33(2): 162-168. 